\title{
Perioperative Precautions for Novel Coronavirus Outbreak
}

\section{Yeni Coronavirüs Salgınında Perioperatif Dönem Korunma Önlemleri}

\author{
(i) Mahmut DAĞCI ${ }^{1}$, id Hatice Merve ALPTEKIN²
}

1Bezmialem Vakıf University Faculty of Health Sciences, Division of Nursing, İstanbul, Turkey

2İstanbul University Cerrahpaşa Florence Nightingale Faculty of Nursing, İstanbul, Turkey

\begin{abstract}
Coronavirus disease 2019 (COVID-19) virus, a sub-member of the coronavirus family, that first appeared in China, has been declared a pandemic in the world due to its rapid spread and spread by airborne transmission. Since all patients diagnosed with COVID-19 do not have symptoms, it is difficult to recognize people with or without disease. When patients with suspected or diagnosed COVID-19 surgery need to be operated in urgent or emergent situations, measures must be taken to protect the patient and the operating room staff. The operating room team should know the procedures to be applied if fixtures and surgical instruments in the operating room are used in cases of suspected COVID-19. In these cases, training should be provided on the effective use of personal protective equipment, precautions to be taken, and health institutions should be able to manage the preoperative, perioperative and postoperative process of patients with suspected COVID-19 or diagnosis. Health institutions should prepare an emergency plan to be applied in pandemic situations. The aim of this was study to present how to manage the perioperative process of surgical patients in COVID-19 pandemic.
\end{abstract}

Keywords: Coronavirus, COVID-19, operating room, surgery, perioperative management

\section{ÖZ}

İlk olarak Çin'de ortaya çıkan coronavirüs ailesinin alt üyesi Coronavirüs hastalığı 2019 (COVİD-19) virüsü, damlacık yoluyla hızlıca bulaşıp yayılması nedeniyle Dünya'da pandemi ilan edilmesine neden olmuştur. COVID-19 tanısı konan hastaların hepsinde semptomlar görülmediğinden hastalığa yakalanmış veya yakalanmamış kişilerin ayrımının yapılması zordur. COVID-19 şüpheli/tanısı doğrulanmış hastaların acil veya ertelenmeyecek durumlarda ameliyat edilmesi gerektiğinde hastayı ve ameliyathane ekibini koruyacak önlemler alınması gerekmektedir. Ameliyathane ekibi ameliyathane odasındaki demirbaşların ve cerrahi aletlerin COVID-19 şüphesi barındıran olgularda kullanılması halinde uygulanacak prosedürleri bilmelidir. Ameliyathane ekibine bu olgular için kişisel koruyucu ekipmanların etkin kullanımı ve alınması gereken önlemler ile ilgili eğitim verilmelidir. Sağlık kurumları da pandemi durumlarında uygulanacak acil durum planını hazırlayarak COVİD-19 şüpheli/tanısı doğrulanmış hastaların preoperatif, perioperatif ve postoperatif sürecini yönetebilmelidir. Bu çalışmada COVİD-19 pandemisinde cerrahi tedavi gereksinimi olan hastaların periopertatif sürecinin nasıl yönetileceğinin anlatılması amaçlanmaktadır.

Anahtar Sözcükler: Coronavirüs, COVİD-19, ameliyathane, cerrahi, perioperatif yönetim
Address for Correspondence: Mahmut DAĞCl, Bezmialem Vakıf University Faculty of Health Sciences, Division of Nursing, istanbul, Turkey

Phone: +90 5547618939 E-mail: mdagci@bezmialem.edu.tr ORCID ID: orcid.org/0000-0003-0883-9129
Received: 08.06.2020

Accepted: 04.08.2020

Cite this article as: Dağcı M, Alptekin HM. Perioperative Precautions for Novel Coronavirus Outbreak. Bezmialem Science 2020;8(Supplement 2):58-62. 


\section{Introduction}

The first case of the COVID-19 [Severe Acute Respiratory Syndrome Coronavirus-2 (SARS-CoV-2)] pandemic, which has surrounded the whole world today and in which $11,669,259$ cases have occurred in the world as of July 8, 2020, and 539,906 of these cases died, emerged in Wuhan city of Hubei state in China at the end of December, 2019 (1-4).

With the occurrence of the cases in the UK at the end of January 2020, the epidemic spread to Europe and the number of cases increased rapidly, resulting in devastating effects on the society $(1,5)$. In Turkey, the first case of COVID-19 was seen on March 11, 2020 (6). The World Health Organization (WHO) declared the COVID-19 pandemic on March 11, 2020, due to the rapid spread of the virus and the rapid increase in pneumonia cases and patients in need of intensive care in parallel with the cases $(7,8)$.

It is known that most of the deaths caused by the COVID-19 virus are seen in individuals with suppressed immune system for any reason, hypertension, diabetes mellitus and comorbid diseases and in the elderly and male populations (9). COVID-19 mortality rates $(0.25-3 \%)$ are not as high as in SARS-CoV-1, but when the transmission rate is compared, SARS-CoV- 1 spreads faster (10). No symptoms or mild symptoms in $80 \%$ of infected patients make it difficult to diagnose the disease. It is stated that $15 \%$ of the patients show severe symptoms and only $5 \%$ of them are in critical condition (11). Fever, cough and mild pneumonia are observed in mild cases. In severe cases, in addition to fever and cough, dyspnea and hypoxia requiring supplementary oxygen therapy are observed. In critical cases, intensive care support is required due to respiratory failure, shock or multi-organ failure $(5,12,13)$. The rapid spread of COVID-19 made it necessary to take measures to manage the epidemic, so it was decided to postpone all elective surgeries $(8,14,15)$. However, it is stated that infected patients should be operated in emergency situations or in cases that cannot be postponed, by taking protective measures (14).

In the studies, it is reported that guides containing the precautions to be taken during the perioperative process to be used in cases with COVID-19 have been prepared for the operating room team (OR head nurses, operating room nurses, surgeons, anesthesiologists, anesthesia technicians, and operating room technicians) $(14,16)$.

In emergency or non-postponed surgical interventions, the preoperative, perioperative and postoperative process management of patients who are suspected for/diagnosed with COVID-19 should be known in detail by the operating room team (14).

In this study, it is aimed to explain how to manage the periopertative process of patients who need surgical treatment in the COVID-19 pandemic.

\section{Measures Taken by Health Institutions}

Considering that COVID-19 infection can spread in hospitals, it is recommended to take general measures to prevent transmission. The main reason for the measures taken is to keep the capacity of the existing health system sufficient against COVID-19 cases, which are expected to increase. In this context, in parallel with the nation-states in the world, non-emergency surgeries have been primarily postponed in Turkey. Later, the Ministry of Health has defined a "pandemic hospital" (6). In order to manage the pandemic process effectively, consumption of medical consumables and surgical applications should be minimized and attention should be paid to the distribution of personnel. It has been reported that operating rooms other than emergency operating rooms can be converted into intensive care units, as the bed capacity is limited for patients in need of intensive care (17). In addition, it is recommended to re-plan shift hours, break times, social distances during meals and rest in order to prevent the spread of COVID-19 among the operating room team $(6,18)$.

Within the scope of COVID-19 measures, a decision tree algorithm has been created in order for the operating room team to evaluate the risk status of the patients $(1,19)$. According to this algorithm, every patient must be considered to be carrying the COVID-19 virus until proven otherwise. In order to prevent the spread of the disease, emergency action plans previously developed by health institutions should be implemented (20). In order to minimize the spread of COVID-19 and protect healthcare personnel, training on personal protective equipment (PPE) is recommended (18). In the study of Forrester et al. (1), they reported that a decision was made to delay the surgical intervention for patients who had a positive COVID-19 test and who had symptoms such as fever, cough and sore throat. In cases where surgical intervention cannot be delayed, reverse transcription-polymerase chain reaction test is performed. While surgical team members perform standard procedures for patients with negative test results, it is reported that all operating room team uses N95 or N99 masks, face guards, surgical gloves, surgical gowns and protective overalls required for droplet isolation for patients with positive test results $(1,21)$.

\section{Preoperative Precautions}

It is recommended that patients with suspected/confirmed COVID-19 infection be transferred to the operating room via a predetermined and isolated path, and the paths and corridors passed by the patient, including elevators, should be disinfected after the transfer is completed (18).

The team transferring the patient should receive special training on "transfer of the patient with risk of transmission through droplets" $(6,18)$. In addition, the use of negative pressure stretchers and ventilators is recommended for patients coming from the intensive care unit (whether intubated or not), and it is reported that the endotracheal tube should be clamped to prevent aerosolization when the gas flow is turned off and the ventilators are changed $(2,16)$.

In order to reduce and control the personnel entry and exit to the operating room, the instruments (intubation tools, anesthetics, peripheral artery/central venous cannulas, injectors, gauze, surgical instruments and sutures) to be used during the operation 
of the patient with COVID-19 should be ready before surgery in line with the recommendations of Association of periOperative Registered Nurses (AORN) (22). In addition, it is recommended to check the devices and anesthetic equipment to be used during surgery beforehand. In the study of Lerardi et al. (23) (2020), it is stated to be important to cover inventory stock, such as the pendants, anesthesia devices, cabinets, tables etc. used in the operating room, with a clear drape for infection control.

Another recommendation is to remove out the equipment such as cabinets and tables that are not needed in the operating room during the preoperative period in order to reduce the surface area where the virus will be transmitted (24). The surgery of the COVID-19 suspected/diagnosed patient includes some different prevention measures, apart from standard infection prevention measures (Figure 1).

PPE used in standard surgical procedures includes surgical mask, surgical shirt, surgical cap, surgical gloves and protective glasses (18). It is recommended to use N95 or N99 masks, protective overalls, shoe covers and face shield in addition to standard prevention measures when performing surgical intervention in patients with suspected/confirmed diagnosis of COVID-19 $(18,21)$. In the study conducted by Tan et al. (3) (2020), the importance of wearing the equipment in front of the mirror is emphasized so that the operating room team can see that the PPE is worn correctly and completely. It is reported that mirrors can be placed in operating rooms to facilitate this application. In addition to all these prevention methods, it is recommended to use



Figure 1. Use of personal protective equipment in the surgery of the patient with suspected/diagnosed COVID-19 * It is recommended to use powered air-purifying respirator in the surgical treatment of patients with suspected/ confirmed COVID-19. devices with active air filtering [(powered air-purifying respirator (PAPR)] in patients with suspected/confirmed COVID-19 (21). It is known that there is water vapor and granular structures in the surgical smoke that occurs when using devices that generate heat energy such as electrocautery (25). Although it is seen as a low possibility, it has been reported that the COVID-19 virus may rise to the water vapor contained in the surgical smoke and contact the healthcare staff (26). PAPR ensures the safety of the operating room team by providing both droplet filtration and filtering electrocautery smoke (21). Although PPE is necessary for the safety of operating room staff, there are difficulties and limitations in working with these equipment. Tan et al. (3) reported in their study that the operating room team had difficulties in wearing PAPR and had problems with battery life, and the face shields they used caused reflection and communication problems. It is recommended to use paper and pencil for written communication to facilitate communication among team members using PPE.

\section{Intraoperative Precautions}

In AORN recommendations, it is recommended to have as few personnel and equipment in the operating room during surgery as possible. There should be a maximum of five health personnel in the room, and entry and exit should be restricted as much as possible (27). In addition, it is recommended that the operating room team perform surgical hand washing in specially reserved areas for the surgery of patients with COVID-19 infection (18). The operating room nurse is responsible for the readiness of the operating room, for him/her and his/her teammates to wear protective equipment (PPE or PAPR), and for taking the patient to the operating table safely (16). Therefore, it is important for the operating room nurse to make the necessary checks before the operation starts. The protection measures to be taken in the operating room are given in Table 1. During the surgery, it is recommended that the healthcare team take precautions for the focus of infection as well as using PPE. WHO reports that there are difficulties in accessing protective equipment during the pandemic period and draws attention to this issue (28). Similarly, in the study conducted by Lai and Chang (29) (2020) in Taiwan, it is seen that researchers try to produce different solutions due to the lack of protective equipment. It is reported that a disposable intubation shield made of cardboard was designed by researchers to be used during the intubation of patients with suspected/confirmed COVID-19. It has been suggested that this face shield can reduce the transmission of infection via droplet during intubation or extubation.

\section{Postoperative Precautions}

In the COVID-19 pandemic, the management of postoperative period includes the transfer of patients to the units and planning for the treatment to be applied. Since postoperative respiratory problems are more common in COVID-19 patients, an interdisciplinary team including anesthesiologists and pulmonologists should decide on the treatment. Post operative planning includes the cleaning of both the operating room and the equipment used in surgery, and the disposal of used consumables. (19). 
Table 1. General protection measures to be taken in the operating room in the COVID-19 pandemic

- Patients with suspected or confirmed disease should be paid more attention (14).

- All personnel who will come into contact with patients should use personal protective equipment (16).

- Infected patients should be moved as little as possible (6).

- Transfer routes should be planned precisely and a short route should be used as much as possible (6).

- During the perioperative process, a safe surgical checklist should be applied and supervised, and if possible, it should be done electronically with touch screen devices to facilitate decontamination (19).

- Surgery of patients with suspected/confirmed COVID-19 should be performed in a separate operating room with isolation precautions. This room should be as close to the patient transfer area as possible (18).

- Since it has been determined that the COVID-19 virus can remain on materials such as stainless steel and plastic in operating rooms for 3 days, disposable materials should be preferred if possible (19).

- After the patient enters the operating room, the doors of the room should be closed and kept closed until the end of the surgery (18).

- There should be as few medical personnel as possible in the operating room (20).

- The operating team should come to the operating room on time and should not leave the room during surgery $(18,27)$

- It is recommended that the number of air changes is $>25$ changes/hour in the operation of the patient with suspected/confirmed COVID-19 (3).

- Patient files and nurse records should be kept outside the operating room (19).

- At the end of each intervention, all surfaces and electromedical devices should be properly disinfected (14).

- The operating room team should remove their personal protective equipment in a specially reserved area outside the room after surgery (14).

- The operating room team should take a shower, if possible, after each operation (18).

The operating room and dressing areas should be disinfected as soon as possible after the operation of patients with suspected/ confirmed COVID-19. $1000 \mathrm{mg} / \mathrm{L}$ sodium hypochlorite solution should be used for cleaning operating rooms and patient contact areas. In addition, it is recommended to use hydrogen peroxide vaporizer or ultraviolet-C irradiation for disinfection $(2,19)$. Reusable surgical instruments should be washed, dried, and decontaminated by disinfection or sterilization process after surgery. It is recommended that electromedical devices (ventilator, electrocautery, etc.) be cleaned with a chloro-derivative solution and then allowed to dry. It is recommended that the devices whose cleaning process is completed are then disinfected with chloro-derivative at a concentration of $\geq 0.1 \%$ or $1000 \mathrm{ppm}$ (18). If there is no visible contamination on devices such as surgical optics or cameras used in the surgery of patients with suspected/ confirmed COVID-19, it is recommended to be kept in 1000 $\mathrm{mg} / \mathrm{L}$ chlorine-containing disinfectant for 30 minutes. If there is visible contamination on these instruments, they should be kept in $5000 \mathrm{mg} / \mathrm{L}$ chlorine-containing disinfectant for 30 minutes and then packaged and sterilized after drying (14).

Disposable materials used in the surgery of the patient with a suspected/confirmed COVID-19 should be disposed of at the end of the surgery. It is recommended to have a separate medical waste container in front of the operating room for medical waste generated during the operation of the patient with suspected/ confirmed COVID-19. Other suggestions include having this medical waste box with a cover, constantly keeping the cover closed, throwing the sharp objects into sharp object container, and replacing the visibly damaged waste containers (18).

\section{Conclusion}

Emergency surgical interventions can be performed even when elective surgeries are postponed during the COVID-19 pandemic. In order for healthcare professionals serving the community to be protected from the virus, health institutions must take the necessary precautions, provide protective equipment and prepare their own pandemic plans.

During the COVID-19 pandemic, it is recommended to conduct more studies with high evidence level on operating room management.

Peer-review: Externally and internally peer reviewed.

\section{Authorship Contributions}

Concept: M.D., H.M.A., Design: M.D., H.M.A., Data Collection or Processing: M.D., H.M.A., Analysis or Interpretation: M.D., H.M.A., Literature Search: M.D., H.M.A., Writing: M.D., H.M.A.

Conflict of Interest: No conflict of interest was declared by the authors.

Financial Disclosure: The authors declared that this study received no financial support.

\section{References}

1. Forrester JD, Nassar AK, Maggio PM, Hawn MT. Precautions for operating room team members during the COVID-19 pandemic. J Am Coll Surg 2020;230:1098-101

2. Karaca AS, Özmen MM, Uçar AD, Yastı AÇ, Demirer S. General surgery operating room applications in patients with COVID-19 . 
Turk J Surg, 2020;36:6-10.

3. Tan Z, Phoon PHY, Jing F, Ting LX. Response and operating room preparation for the COVID-19 outbreak: a perspective from the National Heart Centre Singapore. J Cardiothorac Vasc Anesth 2020;34:2331-3

4. WHO, Coronavirus Disease (COVID-19) Dashboard, Last Accessed Date: 25.05.2020. Available from: https://covid19.who.int/

5. Brücher BL, Nigri G, Tinelli A, Lapeña JFF, Espin-Basany E, Macri P, et al. COVID-19: Pandemic surgery guidance. 4open 2020;3:19.

6. Mavioğlu HL, Ertekin UÜ, Aşkın G, Küçüker ŞA, Özatik MA. Perioperative planning for cardiovascular operations in the COVID-19 pandemic. Turkish J Thorac Cardiovasc Surg 2020;28:236-43.

7. Al-Balas M, Al-Balas HI, Al-Balas H. Surgery during the COVID-19 pandemic: a comprehensive overview and perioperative care. Am J Surg 2020;219:903-6

8. Çakmak G, Cömert M. The Reality of Sars-CoV-2 (COVID-19) and Zonguldak Bülent Ecevit University Faculty of Medicine Department of General Surgery current surgical approach recommendations in the pandemic Process. Batı Karadeniz Tip Derg 2020;4:1-6.

9. Applegate WB, Ouslander JG. COVID-19 presents high risk to older persons. J Am Geriatr Soc 2020;68:681

10. Aktoz M, Altay H, Aslanger E, Atalar E, Atar İ, Aytekin V. ve ark. Türk Kardiyoloji Derneği Uzlaşı Raporu: COVID-19 Pandemisi ve Kardiyovasküler Hastalıklar Konusunda Bilinmesi Gerekenler. Turk Kardiyol Dern Ars 2020;48:1-87.

11. Abdelrahman T, Beamish AJ, Brown C, Egan RJ, Evans T, Ryan Harper E. et al. Surgery during the COVID-19 pandemic: operating room suggestions from an international Delphi process. Br J Surg 2020:10.1002/bjs.11747.

12. Steward J, Kitley WR, Schmidt CM, Sundaram CP. Urologic surgery and COVID-19: How the pandemic is changing the way we operate. J Endourol 2020;34:541-9.

13. Sohrabia C, Alsafi Z, O’Neilla N, Khan M, Kerwan A, Al-Jabir A. World Health Organization declares global emergency: Are view of the 2019 novel coronavirus (COVID-19). Int J Surg 2020;76:71-6.

14. Kamer E, Çolak T. What to do when a patient infected with COVID-19 needs operation: pre-surgery, during surgery, and postsurgery guide. Turk J Colorectal Dis 2020;30:1-8.

15. Flemming S, Hankir M, Ernestus RI, Seyfried F, Germer CT, Meybohm P. et al. Surgery in times of COVID-19-recommendations for hospital and patient management. Langenbecks Arch Surg 2020; 405:359-64.
16. Ti LK, Ang LS, Foong TW, Ng BSW. What we do when a COVID-19 patient needs an operation: operating room preparation and guidance. Can J Anesth 2020;67:756-8..

17. Peters AW, Chawla KS, Turnbull ZA. Transforming ORs into ICUs. New England J Med 2020;382:e52.

18. Coccolini F, Perrone G, Chiarugi M, Di Marzo F, Ansaloni L, Scandroglio I. et al. Surgery in COVID-19 patients: operational directives. World J Emerg Surg 2020;15:25

19. Türk Cerrahi ve Ameliyathane Hemşireliği Derneği. COVID-19 Salgını İçin Ameliyathanede Alınması Gereken Önlemler. 2020. https:/www.tcahd.org/gorseller/ files/covid-19/ COV\%C4\%B0D-19\%20Ameliyat\%20Y\%C3\%B6netimi\%20 Rehberi.pdf.

20. Collaborative C. Global guidance for surgical care during the COVID-19 pandemic. The British Journal of Surgery 2020.

21. Brat GA, Hersey S, Chhabra K, Gupta A, Scott J. Protecting surgical teams during the COVID-19 outbreak: a narrative review and clinical considerations. Ann Surg 2020;17:10.

22. AORN. AORN Position Statement on Perioperative Safe Staffing and On-Call Practices, 2014.

23. Lerardi AM, Wood BJ, Gaudino C, Angileri SA, Jones EC, Hausegger K, Carrafiello G. How to handle a COVID-19 patient in the angiographic suite. Cardiovascular and Interventional Radiology, $2020 ; 1$.

24. Moletta L, Pierobon ES, Capovilla G, Costantini M, Salvador R. ve ark. International Guidelines And Recommendations For Surgery During Covid-19 Pandemic: A Systematic Review. International Journal of Surgery,2020;79:180-188. https://doi.org/10.1016/j. ijsu.2020.05.061.

25. Choi SH, Kwon TG, Chung SK, Kim TH. Surgical smoke may be a biohazard to surgeons performing laparoscopic surgery. Surgical Endoscopy,2014; 28(8):2374-2380.

26. Sookaromdee P, Wiwanitkit V. COVID-19 Among Medical Personnel İn The Operating Room. Infection Control \& Hospital Epidemiology, 2020.

27. AORN. AORN Position Statement on Perioperative Safe Staffing and On-Call Practices, 2014.

28. WHO. Shortage of personal protective equipment endangering health workers worldwide. Newsroom, March, 3, 2020.

29. Lai YY, Chang CM. A carton-made protective shield for suspicious/ confirmed COVID-19 intubation and extubation during surgery. Anesthesia and Analgesia, 2020. 